\title{
METHODOLOGICAL PRINCIPLES OF FORMATION OF READINESS OF FUTURE MASTERS OF MEDICINE FOR PEDAGOGICAL ACTIVITIES
}

\author{
Львівський національний медичний університет імені Данила Галицького \\ МЕТОДОЛОГІЧНІ ЗАСАДИ ФОРМУВАННЯ ГОТОВНОСТІ \\ МАЙБУТНІХ МАГІСТРІВ МЕДИЦИНИ ДО ПЕДАГОГІЧНОЇ \\ ДІЯЛЬНОСТІ
}

В. В. Гуменюк

\begin{abstract}
Requirements of society to the level of training of future masters of medicine for pedagogical activity, able to improve the educational process on the basis of modern technologies, techniques and means of training in the conditions of dynamic transition from theoretical training to independent professional activity, emphasize attention on the revision of the goals, content of the educational process in institutions of higher education on preparation of masters of medicine for pedagogical activity, especially on methodology of development of experience of pedagogical activity at all stages of education. An important aspect of the process of forming the readiness of future masters of medicine for pedagogical activity in the conditions of institutions of higher medical education - is the choice of a set of methodological approaches and their corresponding principles, that influence on the choice of methods and means of training, the construction of a holistic process of vocational training. Considering the formation of readiness for pedagogical activity as a complex and multidimensional process, a full study of which cannot be carried out from one position, it is necessary to respond to axiological, systemic, competent synergetic, active and cultural approaches.

Having researched the problem of a high-quality preparation of future masters of medicine for successful independent pedagogical activity, it was summarized that this process will become more effective conditioning that the professional formation of future masters of medicine will occur as a result of their internal movement on the basis of reflection, self-analysis of their own pedagogical activity and the development of internal motivation for self-improvement and gaining pedagogical experience. This, at the same time, necessitates the improvement of the process of theoretical preparation of future masters of medicine, in particular the introduction of technologies of the activity type, aimed at the development of personal and professional qualities of future teachers in institutions of higher medical education.
\end{abstract}

Key words: readiness for pedagogical activity; future masters of medicine; methodological approaches; vocational training in institutions of higher medical education.

Анотація. Вимоги суспільства до рівня підготовки майбутніх магістрів медицини до педагогічної діяльності, здатних вдосконалювати освітній процес на основі сучасних технологій, прийомів і засобів навчання в умовах динамічного переходу від теоретичного навчання до самостійної професійної діяльності, акцентують увагу на перегляді цілей, змісту освітнього процесу в закладах вищої педагогічної освіти з підготовки магістрів медицини до педагогічної діяльності, особливо на методології розвитку досвіду педагогічної діяльності на всіх етапах навчання. Важливим аспектом процесу формування готовності майбутніх магістрів медицини до педагогічної діяльності в умовах закладів вищої медичної освіти є вибір сукупності методологічних підходів і відповідних їм принципів, що впливають на вибір способів і засобів навчання, побудову цілісного процесу професійної підготовки. Розглядаючи формування готовності до педагогічної діяльності як складний і багатоаспектний процес, повноцінне вивчення якого не може здійснюватися з однієї позиції, необхідним є звернення до аксіологічного, системного, компетентнісного, синергетичного, діяльнісного та культурологічного підходів.

Вивчивши проблему високоякісної підготовки майбутніх магістрів медицини до успішної самостійної педагогічної діяльності, узагальнили, що цей процес стане ефективнішим за умови, якщо професійне становлення майбутніх магістрів медицини буде відбуватися як результат їхнього внутрішнього руху на основі рефлексії, самоаналізу власної педагогічної діяльності та розвитку внутрішньої мотивації до самовдосконалення і набуття педагогічного досвіду. Це, водночас, зумовлює необхідність удосконалення процесу теоретичної підготовки майбутніх магістрів медицини, зокрема впровадження технологій діяльнісного типу, спрямованих на розвиток особистісних і професійних якостей майбутніх викладачів у закладах вищої медичної освіти.

Ключові слова: готовність до педагогічної діяльності; майбутні магістри медицини; методологічні підходи; професійна підготовка в закладах вищої медичної освіти.

(C) V. V. Humeniuk 
Introduction. One of the most important strategic tasks of training highly qualified medical professionals is to modernize the higher medical education system and bring it in line with international requirements. Preparation of a master degree student in higher medical education institutions (HMEI) of Ukraine, in particular for pedagogical activity, is an actual problem for pedagogical analysis. The solution of this problem is directly related to the issue of the necessity of formation of readiness of future masters of medicine for pedagogical activity, who have the ability to organize the educational process in HMEI based on the development of students' personality and experience of their activity, capable quickly involve in pedagogical activity and be ready to improve educational process in the medical school on the basis of modern technologies, techniques and teaching aids [6]. Such high requirements for the Masters of Medicine of the HMEI in the background of their dynamic transition from theoretical training to independent professional activity makes one to reconsider the goals, essence and content of the educational process of training masters of medicine for pedagogical activity, paying particular attention to the methodology of development of pedagogical experience.

The aim - to determine the methodological bases for the formation of future masters' of medicine readiness for pedagogical activity as a result of their preparation in institutions of higher medical educational institutions.

Theoretical framework. One of the actual practical tasks of modern pedagogical science is the task of forming the readiness of future masters of medicine for pedagogical activity, the solution of which is in the plane of interconnection between the increasing the level of professional competence and the level of mastering pedagogical skills by future educators of HMEI. Consideration of this problem in the epistemological and ontological aspects requires, first of all, the establishment of methodological bases for forming the readiness of future masters of medicine for pedagogical activity and explaining the essence of the concept of "readiness for pedagogical activity".

Modern psychological science has accumulated a considerable amount of theoretical and practical material on the problem of readiness for activity in its various forms. Many definitions of readiness have been identified, the content, structure, key parameters of readiness and conditions that influence on the dynamics, duration and stability of its manifestations have been deduced. A review of the scientific literature, that contain readiness definitions, did not provide a single approach. This indicates that a coherent formulation of this concept does not exist due to the availability of different options for its consideration. Focusing on the problem of readiness, which is considered in various aspects, we set the task to analyze the literature and to make a logical conclusion about the essence of the "readiness for activity" concept.

The authors of many theories explain the concept of "readiness for activity" through the different variations of their schools and branches of psychology. In the consideration of the problem of readiness for pedagogical activity, scientists pay main attention to determining of the necessary and sufficient amount of professional knowledge, pedagogical skills and qualities of a personality. Analysis of the structure of psychological readiness for the activity shows that researchers include various components into its structure, filling them with the same content. These include: motivation that leads to a positive attitude to teaching; necessary amount of special and psychologically-pedagogical knowledge; a certain level of pedagogical abilities and skills; complex of professionally significant personality traits. Due to the fact that readiness for action is interpreted as a state of mobilization of all human psychophysiological systems that ensure the effective execution of certain actions, its condition is determined by a combination of factors characterizing different levels and aspects of readiness.

Analyzing the research on the problem of readiness, implemented by various scientists, we generalize about the lack of a unified approach to this issue, but in domestic psychology a readiness for activity is considered by different approaches, the most common of which is personal and functional. The personal approach to readiness is analyzed as an expression of the person's individual qualities and their integrity. For the analysis of readiness from the point of personal approach can be used several components that characterize readiness as a complex mental formation, namely: cognitive process, emotional qualities and volitional component. However, the cognitive process reflects the main limits of activity, emotional qualities predetermine the psychological and physical activity of future masters of medicine, and the volitional component helps to overcome difficulties, if any arise. The essence of the functional approach is found in the assumption that readiness is considered in a time 
(short or long-term) dimension as a certain mental state, which arises as a result of the activation of the psychical functions of the organism, which determine its capability for mental and physical self-mobilization.

Formation of the readiness of future masters of medicine for pedagogical activity in a modern domestic pedagogy should be based on certain methodological approaches. In order to define the essence of each, it should be noted what an approach is as a concept. As I. Sokolova and O. Denysova point out, the approach is an ideology and methodology for solving the problem, which reveal the essence of the main idea, socio-economic, psychological and pedagogical, philosophical preconditions, as well as key objectives, principles, stages and mechanisms for achieving the goals. [13].

An axiological approach should be considered as a key commonly scientific methodological approach, the relevance of the use of which is doubtless. The concept about values is interpreted by scientists as: the concept of material, activity and ideological-spiritual properties, as that, what together forms the sphere of spiritual activity of the individual [8]. In pedagogical axiology, there are classified different groups of values. Among them the values of higher education in the context of globalization, pedagogical values as the basis of professional culture are presented. From the positions of social psychology, the presence of value orientations determines in its totality the stability of future masters of medicine as an individual, because it is "an important factor, that determines the motivation of actions and behavior [11].

The methodological basis for the formation of readiness of future masters of medicine for pedagogical activity is a systemic approach, which guides the research towards discovering the integrity of the object and the mechanisms that maintain it. Since the object of the study is the educational process, whose main pedagogical reference has a practical importance, it should be considered as a system that should harmoniously interact with its environment [4]. The features of this interaction are that it forms a special unity with the environment; as a rule, under research any system is one that can be regarded as an element of the next higher order system; elements of any studied system, at the same time, usually act as systems of the closest lower order to them [7]. The main purpose of the systemic approach is to ensure the integrity of the educational process, to promote its optimization, to consider the process of forming the readiness of future masters of medicine for pedagogical activity as a single system that contains a certain number of internal connections.

The research strategy at the exact scientific level is also a competent approach, which makes it possible to consider the readiness of future masters of medicine for pedagogical activity, to disclose its content and essence as a result of professional training in the conditions of higher medical educational institutions, to determine the criteria and indicators of formation [2]. The implementation of a competency-based approach consists in the objective assessment and self-assessment of the level formation of readiness for pedagogical activity on the basis of developed criteria and indicators that serve as a feedback in personality development; the ability to predict results. The competent approach assumes that the material learned by the student should be oriented towards the preparation of future masters of medicine for creative pedagogical activity and to be correlated with the personal orientation of the learning process by expanding the creative component of professional training in HMEI and the use of multilevel creative tasks of professional orientation that reflect the specifics of vocational training.

Aleading methodological approach is also a synergetic approach, which encompasses a set of principles in the base of which there is the consideration of objects as self-organizing systems. Taking into account that the object of the research is the process of training of future masters of medicine for pedagogical activity, the application of this methodological approach creates conditions for ensuring the self-organization of this process. In the pedagogical system, self-organization involves the presence of a certain interaction between the teacher and students, which meets the requirements of the pedagogical system development, follows from the objective preconditions of its self-movement and allows understanding the mechanism of development of the educational process itself [3].

Pursuing the purpose of practical application of the synergetic approach in the formation of the readiness of future masters of medicine for pedagogical activity, we agree with the formulation of N. Batechko, who considers pedagogical synergetics as a sphere of pedagogical knowledge, which is based on the laws and patterns of development and self-development of personality, self-organization and self-development of pedagogical, that is educational and disciplinary systems [1]. Applying a synergetic approach to creating the structure of the training system of future masters of 
medicine for pedagogical activity should be carried out taking into account the state of this system, which is conditioned by the presence of influence on it by various factors. Such influence goes beyond the limits, foreseen by the parameters of closed systems and can increase due to certain external influence and nonlinearity of internal processes. The role of the synergetic approach and the expediency of its application are due to the fact that to the basis of creation the individual should be included the formation of person's spirituality by developing the spiritual potential of future masters of medicine as individuals.

Another one important specific scientific methodological approach, the application of which is practiced in research, is the activity approach, a necessary condition for the application of which is the development of a system of goals of the educational process, the algorithm of actions of the teachers of the medical university, as well as determining the ways in which they may be motivated to master pedagogical activity. The activity approach used in this study derives from the psychological theory of activity, within which psychological concepts, general psychological problems of activity are developed and considered, as well as the ideas about its structure and mechanisms of self-regulation are formulated. The application of this approach in the research is based on the wellknown fact that outside the activity in pedagogics it is impossible to solve any educational task that is connected with education and development of the individual.

Activity as a social action, that belongs only to one person, in psychology also covers creative, conscious and purposeful types of activity [9], and the structure of the activity always contains the purpose, motive, content, methods and result. It should be noted that according to G. Pichugina [12], there is a certain correlation between the interest of specialists (their role in the research is performed by future masters of medicine), their activity and initiative, on the one hand, and the level of regulation of their teaching professional activity - on the other. [14]. In such circumstances, interest becomes a factor that causes to emerge and further increase the activity of the future masters of medicine.

Thus, the activity approach is a practically oriented tactic of training future masters of medicine for pedagogical activity, it allows to create conditions for formation of readiness of future masters of medicine for pedagogical activity through their involvement in various types of activity (creative play, research, project, etc.), to define content of the education, forms, methods for organizing the activity of future teachers of HMEI.

Among the significant methodological approaches we should mention the culturological approach, which is perceived as a complex of methods of cognition of socio-cultural reality and is used in various fields of social and humanitarian knowledge. The current stage of development of pedagogical science is marked by the search for methodological foundations of the integration of knowledge in different positions. Thus, I. Holub associates the concept of "culturological component" of the educational process with the presence of background knowledge about partners after communication and realities belonging to another culture [5]. Regarding to the concept of "culturology", domestic experts understand it as a science that defines culture as the integrity, system, synthesis of knowledge about the nature and patterns of its existence and development, the importance of culture for humanity, ways of its cognition, as well as different, very specific areas of cultural life, exemplary forms and norms.

Thereby, the set of axiological, systemic, competence synergetic, activity and culturologic approaches determines the possibility of a comprehensive and deep study of the actual problem of forming the readiness of future masters of medicine for pedagogical activity in the conditions of institutions of higher medical education and building a holistic process of professional training.

Conclusions and Prospects for Research. Basing on the outlined methodological principles and approaches, and taking into account the requirements for modern masters of medicine as teachers, the preparation of future masters of medicine for pedagogical activity in HMEI should be carried out with the possibility of independent acquisition of students' knowledge and creation of conditions for the development of professional and personal qualities based on technologies of activity type [15]. For example, the presentation of lecture material from a narrative monologue should be translated into a problem-oriented, paradox-proposing, mindingactive process. Within the framework of the lecture, the main emphasis should be placed on the students' activity, creating conditions for expression of their personal qualities in combination with professional ones, changing the passive position of students to more active. In this case, the process of auditorium 
training of future masters of medicine will provide an evident demonstration of the organization of the learning process. Students will get the opportunity to gain experience in teamwork, communication, organization of a dialogue, debate, polylog. In such situation the development of moral and psychological qualities (organizational, communicative, constructive, expressive, etc.), characteristic for teaching activity is expected.

The organization of independent work of future masters of medicine should also contain active and creative character. This stage is connected with the organization of cultural practice of students' selforganization - purposeful activity, which is aimed

\section{List of literature}

1. Батечко Н. Г. Синергетичний підхід до підготовки фахівців в умовах магістратури / Н. Г. Батечко // Педагогічний процес: теорія і практика. - 2012. - Вип. 4. C. 5-15.

2. Бухальська С. Є. Компетентнісний підхід. Теоретичний аналіз ключових дефініцій вищої медичної освіти / С. Є. Бухальська // Нова педагогічна думка. - 2009. Вип. 2. - С. 84-88.

3. Вознюк О. В. Педагогічна синергетика: генеза, теорія і практика : монографія / О.В.Вознюк. - Житомир : Вид-во ЖДУ імені Івана Франка, 2012. - 708 с.

4. Волкова В. Н. Теория систем и системный анализ : учебник / В. Н. Волкова, А. А. Денисов. - М. : Юрайт, 2010. -679 с.

5. Голуб I. I. Медичний дискурс як тип інституційного спілкування / I. І. Голуб // Медична освіта. - 2011. № 4. - С. 24-27.

6. Гуменюк О. Особливості підготовки магістрів у вищих медичних навчальних закладах України: наскрізна підготовка / О. Гуменюк, В. Гуменюк, С. Цюра // Витоки педагогічної майстерності. - 2017. - Вип. 19. - С. 96-102.

7. Делокаров К. Х. Системная парадигма современной науки и синергетика / К. Х. Делокаров // Общественные науки и современность. - 2000. - № 6. - С. 110-118.

8. Демінська Л. О. Аналіз основних положень аксіологічної науки у філософському та педагогічному аспекті / Л. О. Демінська // Педагогіка, психологія та медикобіологічні проблеми фізичного виховання і спорту. 2011. - Вип. 11. - С. 41-45.

9. Мачинська Н. І. Педагогічна освіта магістрантів вищих навчальних закладів непедагогічного профі- on creation of conditions and organization of their own development [10]. It is important to consider the problem of organization of pedagogical practice, where students can have the opportunity clearly demonstrate the level of readiness for pedagogical activity.

In this manner, if basing on the presented methodological approaches for future masters of medicine in the classroom education there will be created conditions for development of their personal qualities as future teachers and conditions for the development of motivation to gain an experience of pedagogical activity, then the practice will be more active and effective and the level of readiness for pedagogical activity will increase significantly.

лю : монографія / Н. І. Мачинська. - Львів : ЛьвДУВС, 2013. - 416 c.

10. Наскрізна підготовка магістрів медицини з дисципліни «Педіатрія» / Т. П. Борисова, О. Є. Абатуров, Ю. К. Больбот, Л. Р. Шостакович-Корецька // Інновації у вищій медичній та фармацевтичній освіті України : матеріали XVI Всеукр. наук.-практ. конф. 3 міжнар. участю (з дистанційним під'єднанням ВМ(Ф)НЗ України за допомогою відеоконференц-зв'язку) (Тернопіль, 16-17 трав. 2019 р.). - Тернопіль : ТНМУ, 2019. - С. 61.

11. Огнев'юк В. О. Освіта в системі цінностей сталого людського розвитку : монографія / В. О. Огнев’юк. - К. : Знання України, 2003. - 450 с.

12. Пичугина Г. А. Современные педагогические технологии в подготовке студентов к будущей профессиональной деятельности / Г. А. Пичугина // Научное обозрение: гуманитарные исследования. - 2013. - № 3. C. 6-11.

13. Соколова И. И. Развитие научно-исследовательской деятельности у врачей-интернов / И. И. Соколова, Е. Г. Денисова // Современная стоматология. - 2010. № 4. - С. 157-158.

14. Cordella M. A triangle that may workwell: Looking through the angles of a three-way exchange in cancer medicalen counters / M. Cordella // Discourse and Communication. - 2011. - Vol. 5 (4). - P. 336-352.

15. Des Marchais Jacques E. Basic training programin medical pedagogy: a 1-year program for medical faculty / Jacques E. Des Marchais // Canadian Medical Association Journal. - 2009. - Vol. 142 (7). - P. 734-740. 


\section{"PROFESSIONAL AND COMMUNICATION CULTURE OF THE FUTURE DOCTOR: LINGUISTIC, PEDAGOGICAL AND PHILOSOPHICAL ASPECTS”}

\section{References}

1. Batechko, N.H. (2012). Synerhetychnyi pidkhid do pidhotovky fakhivtsiv v umovakh mahistratury [Synergistic approach to the training of specialists in conditions of magistracy]. Pedahohichnyi protses: teoriia i praktyka Pedagogical Process: Theory and Practice, 4, 5-15 [in Ukrainian].

2. Bukhalska, S.Ye. (2009). Kompetentnisnyi pidkhid. Teoretychnyi analiz kliuchovykh definitsii vyshchoi medychnoi osvity [Competency approach. Theoretical analysis of key definitions of higher medical education.]. Nova pedahohichna dumka - New Pedagogical Thought, 2, 84-88 [in Ukrainian].

3. Vozniuk, O.V. (2012). Pedahohichna synerhetyka: heneza, teoriia i praktyka: monohrafiia [Pedagogical synergetics: genesis, theory and practice: monograph.]. Zhytomyr: Vyd-vo ZhDU imeni Ivana Franka [in Ukrainian].

4. Volkova, V.N., \& Denisov, A.A. (2010). Teoriya sistemisistemnyy analiz: uchebnik [Systems theory and systems analysis: a textbook]. Moscow: Yurayt [in Russian].

5. Holub, I.I. (2011). Medychnyi dyskurs yak typ instytutsiinoho spilkuvannia [Medical discourse as a type of institutional communication]. Medychna osvita - Medical Education, 4, 24-27 [in Ukrainian].

6. Humeniuk, O., Humeniuk, V., \& Tsiura, S. (2017). Osoblyvosti pidhotovky mahistriv u vyshchykh medychnykh navchalnykh zakladakh Ukrainy: naskrizna pidhotovka [Features of preparation of masters in higher medical educational establishments of Ukraine: end-to-end preparation]. Vytoky pedahohichnoi maisternosti - Leaks of Pedagogical Skills, 19, 96-102 [in Ukrainian].

7. Delokarov, K.H. (2000). Sistemnaya paradigma sovremennoy nauki i sinergetika [Systemic paradigm of modern science and synergetics]. Obshhestvennye nauki i sovremennost - Social Sciences and Modernity, 6, 110-118 [in Russian].

8. Deminska, L.O. (2011). Analiz osnovnykh polozhen aksiolohichnoi nauky u filosofskomu ta pedahohichnomu aspekti [Analysis of the basic provisions of axiological science in the philosophical and pedagogical aspect]. Pedahohika, psykholohiia ta medyko-biolohichni problem fizychnoho vykhovannia i sportu - Pedagogy, Psychology and Medicalbiological Problems of Physical Education and Sports, 11, 41-45 [in Ukrainian].

9. Machynska, N.I. (2013). Pedahohichna osvita mahistrantiv vyshchykh navchalnykh zakladiv nepedahohichnoho profiliu: monohrafiia [Pedagogical education of undergraduate students of non-pedagogical profile: monograph]. Lviv: LvDUVS [in Ukrainian].

10. Borysova, T.P., Abaturov, O.Ye., Bolbot, Yu.K., Shostakovych-Koretska, L. (2019). Naskrizna pidhotovka mahistriv medytsyny z dystsypliny "Pediatriia”. [Srat-to-end training of Masters in Medicine on "Pediatrics" discipline]. Proceedings of XVI Ukrainian Scient.-Pract. Conf. with International Participation: Innovations in Higher Medical and Pharmaceutical Education in Ukraine (with distant connection of HM(Ph)EI of Ukraine using videoconferenceconnection) [in Ukrainian].

11. Ohneviuk, V.O. (2003). Osvita v systemi tsinnostei staloho liudskoho rozvytku: monohrafiia [Education in the system of values of sustainable human development: a monograph]. Kyiv: Znannia Ukrainy [in Ukrainian].

12. Pichugina, G.A. (2013). Sovremennye pedagogicheskie tekhnologii v podgotovke studentov k budushhey professionalnoy deyatelnosti [Modern pedagogical technologies in preparing students for future professional activity]. Nauchnoe obozrenie: gumanitarnye issledovaniya - Scientific Review: Humanitarian Research, 3, 6-11 [in Russian].

13. Sokolova, I.I., \& Denisova, E.G. (2010). Razvitie nauchno-issledovatelskoy deyatelnosti u vrachey-internov [Development of scientifically-research activity in doctorsinterns]. Sovremennaya stomatologiya-Modern Dentistry, 4, 157-158 [in Russian].

14. Cordella, M.A. (2011). A triangle that may workwell: Looking through the angles of a three-way exchange in cancer medicalen counters. Discourse and Communication, 5 (4), 336-352.

15. DesMarchais, Jacques E. (2009). Basic training program in medical pedagogy: a 1-year program for medical faculty. Canadian Medical Association Journal, 142 (7), 734-740. 